\title{
Identifikasi Suara Tangisan Bayi menggunakan Metode LPC dan Euclidean Distance
}

\section{IRMA AMELIA DEWI ${ }^{1}$, ADRIANA ZULKARNAIN ${ }^{2}$, AYU APRILIA LESTARI ${ }^{3}$}

\author{
1,3Institut Teknologi Nasional Bandung \\ 2Universitas Langlangbuana Bandung \\ Email: irma_amelia@itenas.ac.id
}

Received 18 Desember 2017 | Revised 22 Januari 2018 | Accepted 23 Januari 2018

\begin{abstract}
ABSTRAK
Kebanyakan orang tua masih jarang memiliki kemampuan mengartikan tangisan bayi. Bagi beberapa orang tua hal tersebut menjadi kendala ketika mengenali kebutuhan dari tangisan bayi. Oleh karena itu, pada penelitian ini telah diirancang sistem mengidentifikasi suara tangisan bayi dengan metode ektstraksi sinyal yaitu metode LPC (Linear Predictive Coding) dan pencocokan pola menggunakan algoritma Euclidean Distance. Data latih tangisan bayi menggunakan database suara Baby language-DBL, sementara data uji suara tangisan bayi diperoleh dari hasil observasi di poliklinik anak suatu rumah sakit. Proses diawali dengan mengektraksi file suara tangisan bayi dan disimpan ke dalam database sebagai data latih. Suara data uji diekstraksi kemudian dicocokkan dengan data latih menggunakan Euclidean Distance. Aplikasi dapat mengidentifikasi suara tangisan bayi dengan hasil pencocokan sebesar $76 \%$.
\end{abstract}

Kata kunci: Tangisan Bayi, Linear Predictive Coding, Euclidean Distance, Dunstan Baby Language

\begin{abstract}
Most parents still rarely have the ability to interpret the infant cries. Some parents become an obstacle when recognizing the needs of crying babies. Therefore, this research has designed the system to identify the sound of crying baby with method of signal extraction that is LPC (Linear Predictive Coding) method and pattern matching using Euclidean Distance algorithm. Training dataset of infant cries using the Dunstan Baby language database-DBL, while testing dataset of infant cries were obtained from observations in the child polyclinic of a hospital. The process begins by extracting training dataset from the sound of infant cries files and stored in the database. The extraction feature of testing dataset is matched with the training data using the Euclidean Distance. The system can identify the sound of crying babies with matching results of $76 \%$.
\end{abstract}

Keywords: Infant Cries, Newborn Cries, Linear Predictive Coding, Euclidean Distance, Dunstan Baby Language 


\section{PENDAHULUAN}

Tangisan bayi merupakan salah satu cara yang paling berpengaruh untuk mengungkapkan kondisi fisik dan psikologi. Kebanyakan orang tua masih jarang memiliki pengetahuan mengartikan kondisi bayi dari tangisan sehingga dapat menimbulkan kebingungan dan salah menerjemahkan kebutuhan dan kondisi bayi. Tangisan bayi juga dianggap sebagai bentuk dari kondisi tidak normal pada kesehatan bayi, sehingga tidak sedikit penelitian yang mengungkapkan arti tangisan terhadap kondisi kesehatan bayi.

Hampir semua bayi usia 0-3 bulan memiliki jenis tangisan awal yang sama sebelum akhirnya menangis histeris karena kondisinya tidak ditanggapi dengan tepat oleh orangtuanya. Tangisan awal pada usia 0-3 bulan dapat diklasifikasikan berdasarkan kebutuhannya yang dikenal dengan Dunstan Baby Language/DBL (Dunstan, 2006). Bayi yang baru lahir memiliki refleks primitif, yaitu beberapa gerakan atau suara spontan yang terjadi sebagai bagian dari aktivitas bayi yang biasa. Sama halnya reflek suara pada kebanyakan manusia seperti bersin, cegukan, dan bersendawa yang memiliki pola sinyal suara yang dapat dikenali. Pada usia bayi 6-10 bulan reflek primitif tersebut akan mulai menghilang karena kemampuan bayi dalam beradaptasi dengan lingkungan sekitar mulai berkembang (Moeckel \& Mitha, 2008). Tangisan bayi universal dibagi menjadi 5 jenis klasifikasi yaitu "neh" berarti lapar, "owh" berarti lelah atau mengantuk, "eh" berarti ingin bersendawa, "eairh" berarti nyeri, dan "heh" berarti tidak nyaman (Dunstan, 2006) (Smith, 2013).

Beberapa penelitian telah dilakukan untuk menentukan kebutuhan dan kondisi bayi dari tangisan suara, seperti yang dilakukan (Renanti dkk, 2013) mengidentifikasi tangisan bayi menggunakan Codebook dan MFCC menghasilkan keakurasian 37\% dan 94\%. Pada penelitian tersebut suara 'eh' memiliki tingkat akurasi lebih tinggi sementara 'owh' memiliki tingkat akurasi rendah karena sering teridentifikasi sebagai suara 'neh' atau 'eairh'. Penelitian serupa (Srijiranon, Eiamkanitchat, 2014) mengidentifikasi tangisan bayi menggunakan teknik Neuro-Fuzzy untuk mengklasifikasikan dan Perceptual Linear Prediction untuk mengenali tangisan bayi. Adapula (Limantoro dkk, 2016) mengidentifikasi suara tangisan bayi menggunakan MFCC dan K-NN memperoleh keakurasian rata-rata sebesar $96.57 \%$. Sementara (Ariyadi dkk, 2016) telah melakukan penelitian mengenai pengenalan rasa lapar melalui suara tangisan bayi pada bayi usia 0-9 bulan dengan menggunakan Transformasi Wavelet Kontinyu dan Neural Network dengan persentase keakuratan pengenalan sinyal suara sebesar $89.7 \%$. Tangisan bayi juga dapat digunakan untuk mendeteksi kondisi kesehatan bayi seperti penelitian (Hariharan dkk, 2012) mengklasifikasikan tangisan bayi normal dan tangisan bayi menderita ketulian menggunakan Multiplayer Perceptron dan Time-Delay Neural Network, (Poel, Ekkel, 2006) penelitian yang mengklasifikasikan tangisan bayi normal dan yang menderita Hypoxia-Related Disorder menggunakan Probabilistic Neural-Network dengan tingkat akurasi $85 \%$

Berdasarkan beberapa penelitian yang telah dilakukan dan permasalahan tersebut maka dapat ditarik rumusan masalah bahwa menentukan kebutuhan bayi bahkan kesehatan dan kondisi bayi dapat dilakukan dengan mengidentifikasi melalui suara tangisan terutama bayi khususnya bayi pada usia 0-9 bulan. Oleh karena itu, penelitian ini fokus kepada merancang aplikasi mendeteksi kebutuhan bayi melalui suara pada usia 0-3 bulan dengan menggunakan database suara DBL yang dibangun menggunakan metode LPC (Linear Predictive Coding). Pada penelitian ini LPC digunakan sebagai metode ekstraksi sinyal suara untuk mendapatkan model yang merepresentasikan suara dan pencocokannya antara suara uji dan latih menggunakan Algoritma Euclidean Distance untuk mendapatkan pola yang identik cocok. Pada penelitian ini 
menggunakan sample rate suara $16000 \mathrm{~Hz}$ dan durasi minimum 2 detik dalam proses pengidentifikasiannya.

\section{TINJAUAN PUSTAKA}

\subsection{Dunstan Baby Language (DBL)}

Dunstan Baby Language atau DBL diperkenalkan pertama kali oleh Priscilla Dunstan, seorang musisi asal Australia yang memiliki kemampuan untuk mengingat semua jenis suara yang disebut dengan sound photograph. Dunstan sudah melakukan riset selama 6 tahun untuk mengenali jenis tangisan bayi (Bhagatpatil \& Sardar, 2014). Berdasarkan hasil penelitiannya bahwa bayi pada rentan usia 0-3 bulan memiliki jenis suara reflek primitif yang sama terlepas dari budaya dan kelompok linguistik memiliki arti yang berbeda (Brătilă, Comandasu, Diaconescu, Rusu, \& Sardescu, 2015). Suara reflek primitif sama halnya seperti reflek suara pada orang bersendawa, bersin atau cegukan.

\subsection{Linier Predictive Coding(LPC)}

Terdapat beberapa penelitian yang menggunakan metode LPC karena menurut (Rabiner, Juang, 1993) LPC memiliki kelebihan yaitu sederhana dan dapat diterapkan pada perangkat lunak dan keras. LP memiliki dua komponen utama yaitu Encoding dan Decoding. Bagian encoding digunakan untuk memeriksa dan membagi sinyal suara menjadi beberapa bagian, sedangkan decoding digunakan untuk mengubah suara yang telah diproduksi. Gambar 1 menunjukkan proses metode LPC.

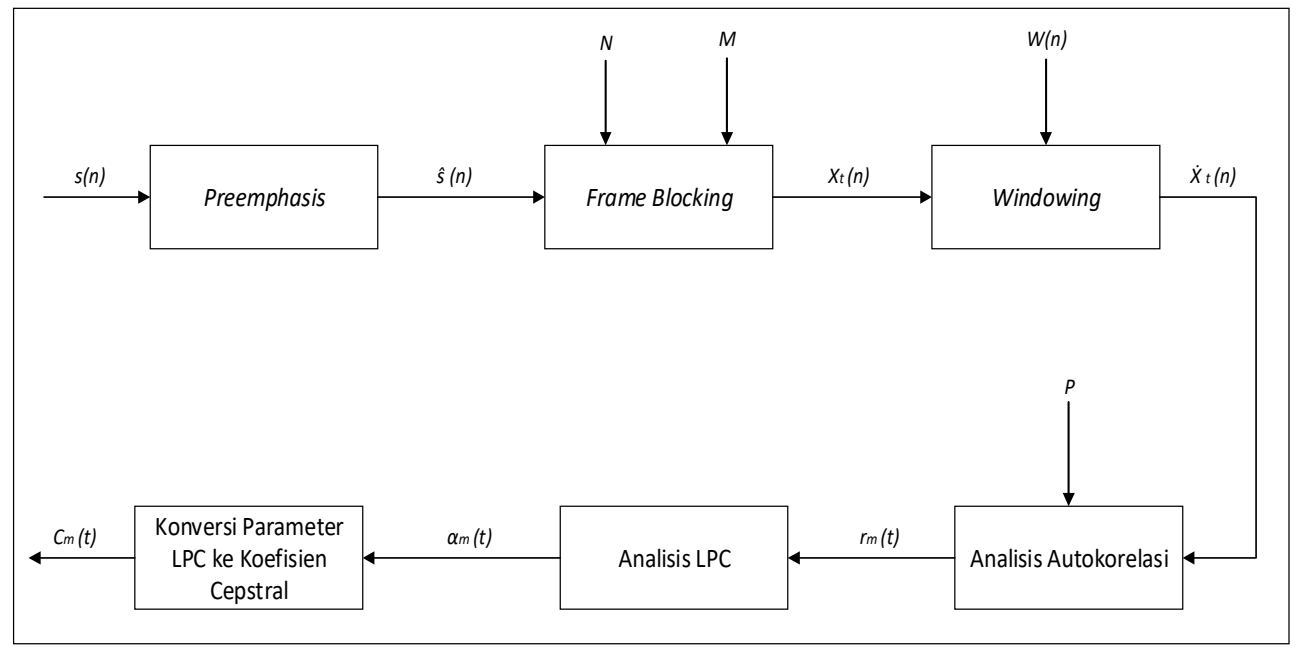

Gambar 1. Proses Umum Algoritma LPC (Rabiner, Juang, 1993)

Pada Gambar 1 dapat dilihat bahwa tahapan metode LPC melalui beberapa tahapan berikut (Rabiner, Juang, 1993):

1. Pre-emphasis merupakan proses menghilangkan noise suara dari suara masukan. Noise ini berupa sinyal yang memiliki perbedaan signifikan di antara nilai di sekitarnya.

2. Frame Blocking merupakan proses membagi sinyal suara menjadi beberapa blok suara.

3. Windowing merupakan tahapan untuk memeriksa dan mengurangi diskontinu dari sinyal yang telah dibagi menjadi beberapa segmen.

4. Analisis Autokorelasi adalah proses mengkorelasikan setiap sinyal dari masing-masing frame. 
5. Analisis LPC adalah proses mengubah nilai yang sudah di-autokorelasi menjadi nilai parameter LPC, yaitu koefisien LPC, koefisien pantulan, koefisien perbandingan daerah logaritmis.

6. Konversi parameter LPC ke koefisien Ceptral adalah merupakan koefisien yang diperoleh dari representasi spektrum transformasi Fourier (Rachman, 2011).

\subsection{Euclidean Distance}

Jarak Euclidean digunakan untuk mengukur kemiripan nilai ekstraksi data uji dengan seluruh data latih yang lain dapat diukur dengan menggunakan formula Phytagoras.

$$
d=\sqrt{\sum_{i}^{n}(W i-X i)^{2}}
$$

Dimana:

$\mathrm{d}=$ jarak Euclidian

$\mathrm{Wi}=$ vektor bobot ke-i

$\mathrm{Xi}=$ vektor input ke $\mathrm{Xi}$

Semakin kecil jarak yang diperoleh (d), maka semakin besar kemiripan antara kedua objek dan sebaliknya, jika semakin besar jarak yang diperoleh (d), maka semakin kecil kemiripan antara dua objek (Deza \& Deza, 2009).

\section{METODOLOGI PENELITIAN}

Aplikasi Identifikasi Tangisan Bayi memiliki beberapa tahapan cara kerja sistem yang dapat dilihat pada Gambar 2.

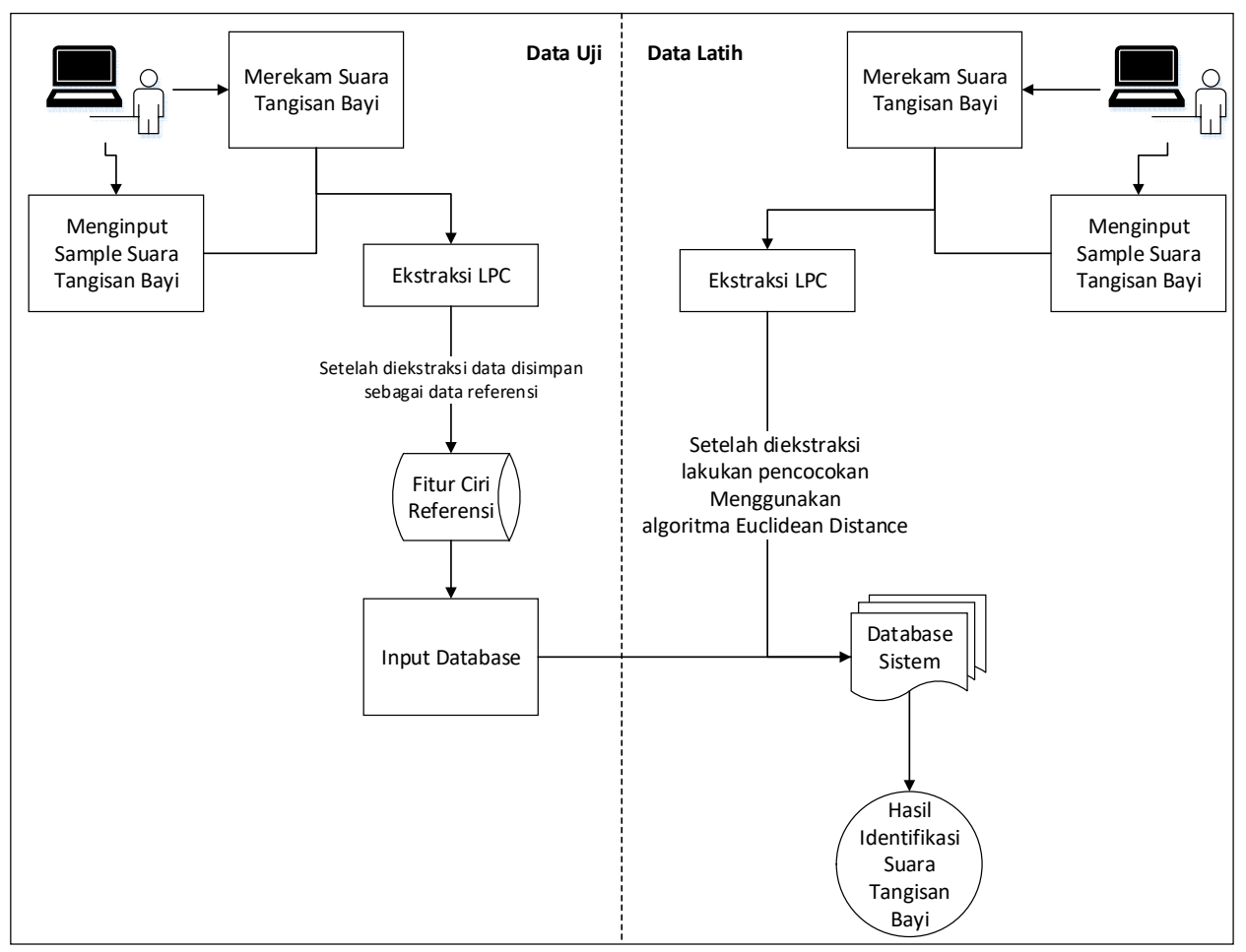

Gambar 2. Cara Kerja Sistem 
Sistem ini dibagi menjadi dua tahap yaitu proses pelatihan dan proses klasifikasi/pencocokan. Proses pelatihan dan pencocokan/pengujian memiliki tahapan yang sama hanya saja pada tahap pelatihan data suara yang telah diekstraksi disimpan ke basis data suara latih. Data latih suara bayi menggunakan bank suara dari DBL (Dunstan Baby Language). Selanjutnya sistem masuk ke tahap resize untuk menyamakan ukuran panjang suara. Tahap selanjutnya adalah proses ekstraksi ciri yang menggunakan Linear Predictive Coding (LPC) yang menghasilkan vektor. Pada proses pelatihan setelah tahap ekstraksi ciri selanjutnya dilakukan tahap pencocokan sinyal suara data yang diujikan dengan data latih dalam database menggunakan Euclidean Distance. Tahap pencocokan dengan Euclidean Distance mengklasifikasikan bobot suara uji dengan yang ada didalam data latih. Bobot file suara uji yang mendekati bobot target, maka teridentifikasi suara tangisan bayi. Jika bobotnya terlalu jauh dengan bobot target maka hasilnya tidak akan sesuai. Metode Euclidean Distance ini hanya mencari bobot terkecil dari data uji.

\subsection{Ekstraksi Ciri}

Setelah memperoleh ukuran panjang suara yang sama selanjutnya dilakukan proses ekstraksi menggunakan LPC sesuai pada Gambar 1.

\section{a. Pre-emphasis}

Tahap pertama adalah menghilangkan noise suara yang tidak dibutuhkan. Noise ini berupa sinyal yang memiliki perbedaan signifikan di antara nilai di sekitarnya. Pada tahapan ini diterapkan Persamaan 2 (Deng, O'Shaughnessy,2003):

$$
\mathrm{y}(n)=s(n)-\alpha \cdot s(n-1)
$$

Pada proses ini nilai alpha yang digunakan adalah 0,95 sebagai nilai alpha default. Misalkan sampel sinyal : (-22.125, -46.125, -26.125, -2.125, 17.875, 27.875, 32.875, 17.875), dengan $a=0.95$ dengan menerapkan Persamaan 2, maka diperoleh:

$$
\begin{array}{ll}
\text { Y0 }=-22,125 & =-25,1 \\
\text { Y1 }=(-46,125)-(-22,125 * 0,95) & =17,7 \\
\text { Y2 }=(-26,125)-(-46,125 * 0,95) & =22,7 \\
\text { Y3 }=(-2,125)-(-26,125 * 0,95) & =19,9 \\
\text { Y4 }=17,875-(-2,125 * 0,95) & =10,9 \\
\text { Y5 }=27,875-(17,875 * 0,95) & =6,4 \\
\text { Y6 }=32,875-(27,875 * 0,95) & =-13.4 \\
\text { Y7 }=17,875-(32,875 * 0,95) &
\end{array}
$$

Data sinyal baru adalah data sinyal sebelum proses pre-emphasis ditambah dengan data hasil pre-emphasis diatas. Sehingga sinyal setelah pre-emphasis :

$$
\begin{aligned}
& \mathrm{Nn}=\mathrm{Nn}+\mathrm{Yn} \\
& \mathrm{N} 0=-22,125+(-22,125)=-44,25
\end{aligned}
$$

Begitu juga dengan ketujuh data yang lainnya, sehingga didapatkan nilai sinyal setelah preemphasis adalah :

$$
(-44.3,-71,1,-8,4,20.6,37.8,38.8,39.3,4.8)
$$

Hasil sinyal suara sebelum dan setelah dilakukan proses pre-emphasis yang terlihat pada Gambar 3 dan Gambar 4. 


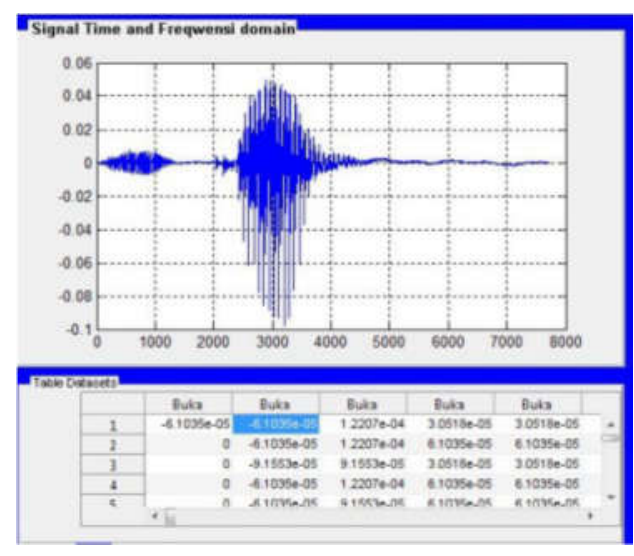

Gambar 3. Sinyal Suara sebelum Proses Pre-emphasis Suara "Owh"

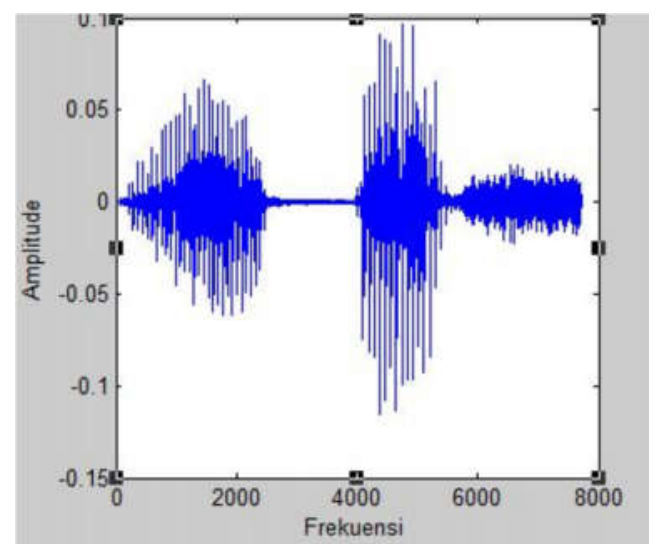

Gambar 4. Sinyal Suara setelah Proses Pre-emphasis Suara "Owh"

\section{b. Frame Blocking}

Tahap berikutnya ada membagi sinyal suara yang sudah dikurangi noisenya menjadi beberapa bagian. Pada penelitian ini sinyal suara dipotong sepanjang $20 \mathrm{~ms}$ di setiap pergeseran sepanjang $10 \mathrm{~ms}$.

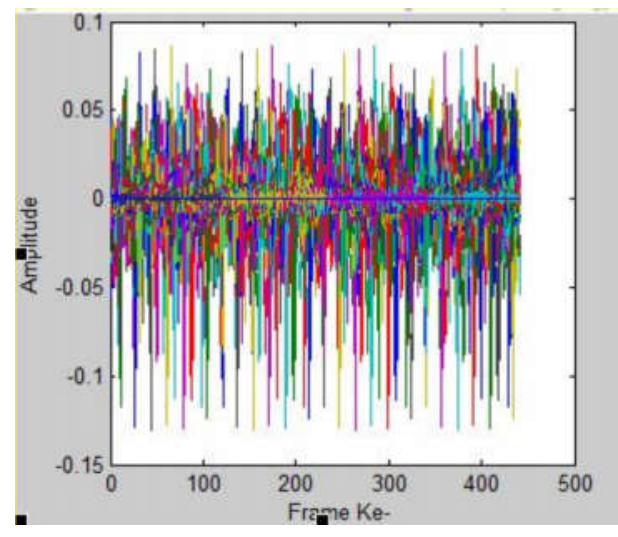

\section{Gambar 5. Sinyal Proses Frame Blocking}

\section{c. Windowing}

Pada tahapan frame blocking ada kemungkinan terdapat sinyal yang terputus-putus atau mengalami diskontinuitas antara blok satu dengan yang lainnya, sehingga pada tahapan windowing dilakukan untuk mengurangi efek tersebut. Dengan menerapkan Persamaan 3 (Rabiner, Juang, 1993) dengan asumsi jumlah sample masing-masing frame atau $\mathrm{N}$ adalah 640, sehingga diperoleh $w(n)$ sebagai berikut:

$$
w(n)=0,54-0,46 \cos \left(\frac{2 \pi \mathrm{n}}{\mathrm{N}-1}\right)
$$

$$
\mathrm{w} 0=0.54-0.46 \cos \frac{2 * 3.14 * 0}{640-1}=0.08
$$

Sehingga, $\mathrm{W} 0=-44.5 * 0.08=-3.54$ 
Dengan cara yang sama tujuh sampel titik lainya yang diperoleh pada tahap sebelumnya dapat diperoleh nilai windowing. Hasil sinyal suara setelah dilakukan proses windowing dapat dilihat pada Gambar 6.

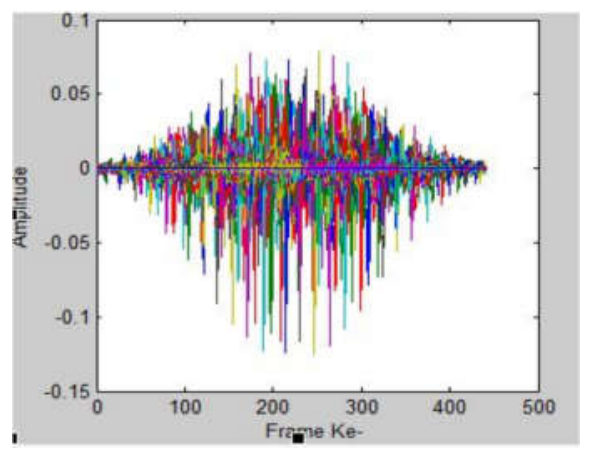

\section{Gambar 6. Sinyal Suara Proses Windowing}

\section{d. Analisis Autokorelasi}

Bagian sinyal yang telah melalui tahap windowing, dibentuk autokorelasinya dengan Persamaan 4 berikut:

$$
r(m)=\Sigma_{n=0}^{N-1-m} \tilde{x}(n) \cdot \tilde{x}(n+m), \quad \mathrm{m}=0,1,2, \ldots, \mathrm{p}
$$

Order analisis LPC memiliki nilai umum antara 8 sampai dengan 16. (Thiang, Saputra, 2005).

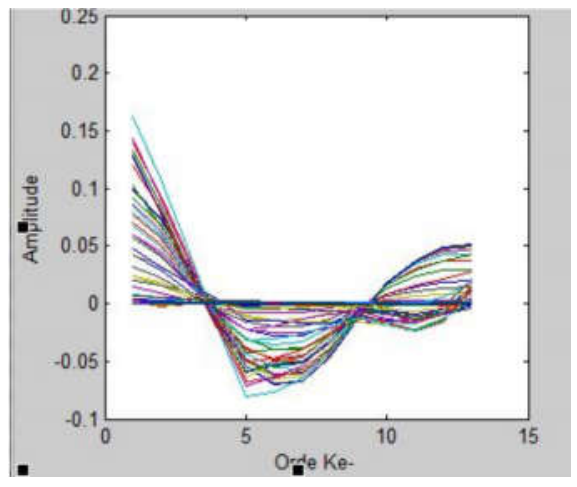

\section{Gambar 7. Sinyal Suara Proses Autokorelasi}

\section{e. Analisis LPC}

Proses ini dilakukan untuk mengubah nilai autokorelasi menjadi parameter koefisien transformasi. Pada tahap ini akan menghasilkan sinyal suara seperti Gambar 8 melalui perhitungan berikut (Rachman, 2011):

$$
\left[\begin{array}{ccccc}
R_{n}(0) & R_{n}(1) & R_{n}(2) & \ldots & R_{n}(p-1) \\
R_{n}(1) & R_{n}(0) & R_{n}(1) & \ldots & R_{n}(p-2) \\
R_{n}(2) & R_{n}(1) & R_{n}(0) & \ldots & R_{n}(p-3) \\
\ldots & \ldots & \ldots & \ldots & \ldots \\
\ldots & \ldots & \ldots & \ldots & \ldots \\
R_{n}(p-1) & R_{n}(p-2) & R_{n}(p-3) & \ldots & R_{n}(0)
\end{array}\right]\left[\begin{array}{c}
\alpha_{1} \\
\alpha_{2} \\
\alpha_{3} \\
\ldots \\
\ldots \\
\alpha_{p}
\end{array}\right]=\left[\begin{array}{c}
R_{n}(1) \\
R_{n}(2) \\
R_{n}(3) \\
\ldots \\
\ldots \\
R_{n}(p)
\end{array}\right]
$$




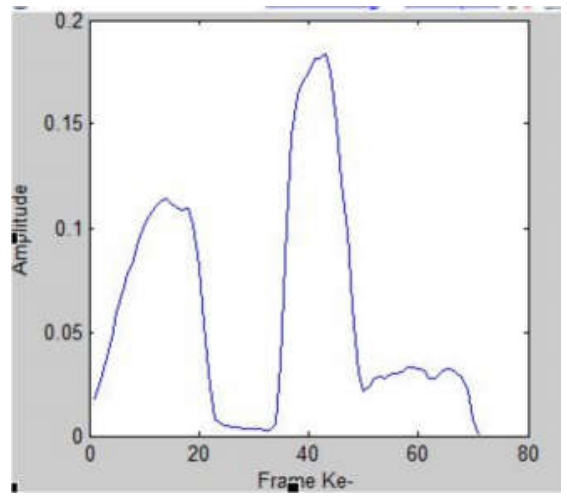

Gambar 8. Sinyal Suara Proses AnalisisLPC

\section{f. Pengubahan Parameter LPC ke Koefisien Cepstral}

Koefisien cepstral ini adalah koefisien dari representasi transformasi Fourier pada spectrum logaritmis (Thiang \& Saputra, 2005).

dengan nilai $\mathrm{m}$ adalah $1 \leq m \leq p$

$$
c_{m}=a_{m}+\sum_{k=1}^{m-1}\left(\frac{k}{m}\right) \cdot c_{k} \cdot a_{m-k}
$$

$$
c_{m}=\sum_{k=1}^{m-1}\left(\frac{k}{m}\right) \cdot c_{k} \cdot a_{m-k}
$$

dengan nilai $\mathrm{m}$ adalah $m>p$

Perhitungan-perhitungan LPC di atas menggunakan pemilihan $\mathrm{N}=400 \mathrm{M}=160$. Hasil dari koefisien cepstral yang didapat digunakan sebagai fitur ekstraksi ciri. Berikut contoh hasil koefisien cepstral yang terlihat pada Gambar 9.

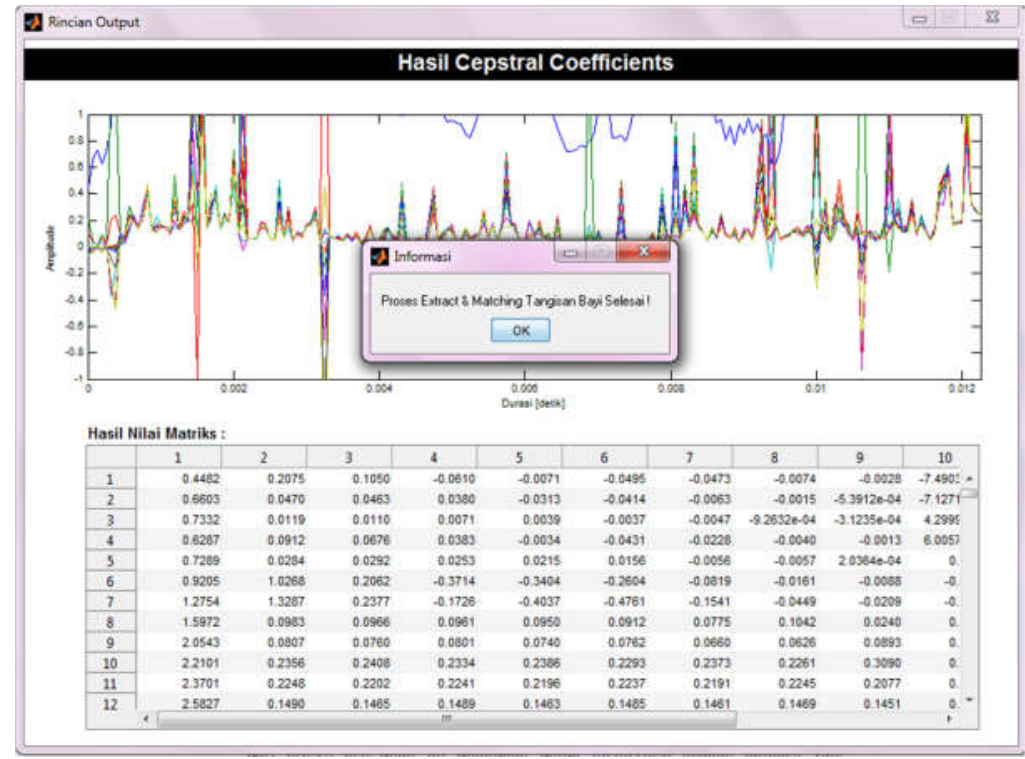

Gambar 9. Hasil Koefisien Cepstral 


\section{HASIL DAN PEMBAHASAN}

\subsection{Proses Pengambilan Sampel Suara Data Uji}

Pada proses pengujian dilakukan observasi dan perekaman suara tangisan bayi di poli sebuah rumah sakit sebanyak 25 sampel suara, yaitu 5 sampel suara untuk "neh", 5 sampel suara "eh", 5 sampel suara "heh", 5 sampel suara "eairh", 5 sampel suara "owh". Sementara data latih diambil dari database suara Dunstan baby language (DBL).

\subsection{Pengujian Sistem}

Pada proses pengujian dilakukan pencocokan bobot suara dari data uji dengan data latih menggunakan Euclidean Distance pada Persamaan 1. Hasil identifikasi berdasarkan nilai pencocokan dengan bobot paling kecil dari perhitungan data uji dengan seluruh data latih.

Tabel 1. Pengujian Pencocokan Euclidean Distance

\begin{tabular}{|c|c|c|c|}
\hline Data Uji & $\begin{array}{l}\text { Data Latih } \\
\end{array}$ & Nilai Pencocokan & Hasil Identifikasi \\
\hline \multirow{25}{*}{$\begin{array}{l}\text { Suara_Uji } 2 \\
(198 \times 13) \\
0.4989\end{array}$} & Ingin Sendawa $1(0.000013943)$ & 0.248887 & \multirow{25}{*}{ Nyeri } \\
\hline & Tidak Nyaman 1 (0.00000051233) & 0.248901 & \\
\hline & Nyeri $1(0.0333)$ & 0.216783 & \\
\hline & Lapar $1(0.0048)$ & 0.244135 & \\
\hline & Lelah $1(0.000012289)$ & 0.248889 & \\
\hline & Ingin Sendawa $2(0.000021169)$ & 0.24888 & \\
\hline & Tidak Nyaman $2(0.00044456)$ & 0.248458 & \\
\hline & Nyeri $2(0.00034554)$ & 0.248557 & \\
\hline & Lapar $2(0.0013)$ & 0.247606 & \\
\hline & Lelah $2(0.0000082072)$ & 0.248893 & \\
\hline & Ingin Sendawa 3 (0.000023299) & 0.248878 & \\
\hline & Tidak Nyaman 3 (0.00004107) & 0.24886 & \\
\hline & Nyeri $3(0.00000017565)$ & 0.248901 & \\
\hline & Lapar $3(0.0000012726)$ & 0.2489 & \\
\hline & Lelah 3 (0.0000014329) & 0.2489 & \\
\hline & Ingin Sendawa 4 (0.00001641) & 0.248885 & \\
\hline & Tidak Nyaman 4 (0.00000023799) & 0.248901 & \\
\hline & Nyeri $4(0.0611)$ & 0.191669 & \\
\hline & Lapar $4(0.0000001459)$ & 0.248901 & \\
\hline & Lelah 4 (0.0000021949) & 0.248899 & \\
\hline & Ingin Sendawa 5 (0.0000051107) & 0.248896 & \\
\hline & Tidak Nyaman $5(0.00000065833)$ & 0.248901 & \\
\hline & Nyeri $5(0.00000004943)$ & 0.248901 & \\
\hline & Lapar $5(0.00000060921)$ & 0.248901 & \\
\hline & Lelah 5 (0.00000007034) & 0.248901 & \\
\hline
\end{tabular}

Dari Tabel 1, diperoleh bobot terkecil dari hasil perhitungan Euclidean Distance antara nilai suara data uji dan latih adalah 0.191669 diidentifikasi sebagai tangisan bayi "eairh" yang mengindikasi rasa nyeri.

Hasil pada tabel terlihat bahwa, dari 25 suara tangisan bayi uji terdapat 6 suara tangisan bayi uji mengalami kesalahan identifikasi, dominan kesalahan untuk identifikasi sistem dengan jenis tangisan 'eairh' atau nyeri mendekati dengan bobot pada suara tangisan 'owh' lelah dan 'heh' tidak nyaman. Pada Tabel 2 merupakan hasil pengujian pencocokan 25 data uji suara tangisan bayi. 
Tabel 2. Hasil Pengujian Suara Tangisan Bayi

\begin{tabular}{|c|c|c|}
\hline Suara Tangisan Bayi & Indikasi Sebenarnya & Identifikasi Sistem \\
\hline Suara_Uji 1 & Lapar $(0.00026811)$ & Lapar \\
\hline Suara_Uji 2 & Nyeri $(0.4989)$ & Nyeri \\
\hline Suara_Uji 3 & Ingin Sendawa $(0.000017244)$ & Ingin Sendawa \\
\hline Suara_Uji 4 & Lelah $(0.00000013857)$ & Lelah \\
\hline Suara_Uji 5 & Tidak Nyaman (0.0026) & Nyeri (2) \\
\hline Suara_Uji 6 & Lapar $(0.0000081884)$ & Lapar \\
\hline Suara_Uji 7 & Nyeri $(1.0011)$ & Nyeri \\
\hline Suara_Uji 8 & Ingin Sendawa (0.0053) & Nyeri (1) \\
\hline Suara_Uji 9 & Lelah $(0.0521)$ & Nyeri (1) \\
\hline Suara_Uji 10 & Tidak Nyaman (0.0011) & Nyeri (2) \\
\hline Suara_Uji 11 & Lapar (0.0073) & Lapar \\
\hline Suara_Uji 12 & Nyeri $(0.0322)$ & Nyeri \\
\hline Suara_Uji 13 & Ingin Sendawa (0.000314) & Ingin Sendawa \\
\hline Suara_Uji 14 & Lelah (0.3139) & Nyeri (2) \\
\hline Suara_Uji 15 & Tidak Nyaman $(0.000053432)$ & Tidak Nyaman \\
\hline Suara_Uji 16 & Lapar (0.000033979) & Lapar \\
\hline Suara_Uji 17 & Nyeri $(0.2614)$ & Nyeri \\
\hline Suara_Uji 18 & Ingin Sendawa $(0.00004162)$ & Ingin Sendawa \\
\hline Suara_Uji 19 & Lelah $(0.00037317)$ & Nyeri (2) \\
\hline Suara_Uji 20 & Tidak Nyaman (0.1544) & Tidak Nyaman \\
\hline Suara_Uji 21 & Lapar (0.00000097406) & Lapar \\
\hline Suara_Uji 22 & Nyeri $(0.0062)$ & Nyeri \\
\hline Suara_Uji 23 & Ingin Sendawa (0.00001266) & Ingin Sendawa \\
\hline Suara_Uji 24 & Lelah $(0.0000018329)$ & Lelah \\
\hline Suara_Uji 25 & Tidak Nyaman $(0.0000006051)$ & Tidak Nyaman \\
\hline
\end{tabular}

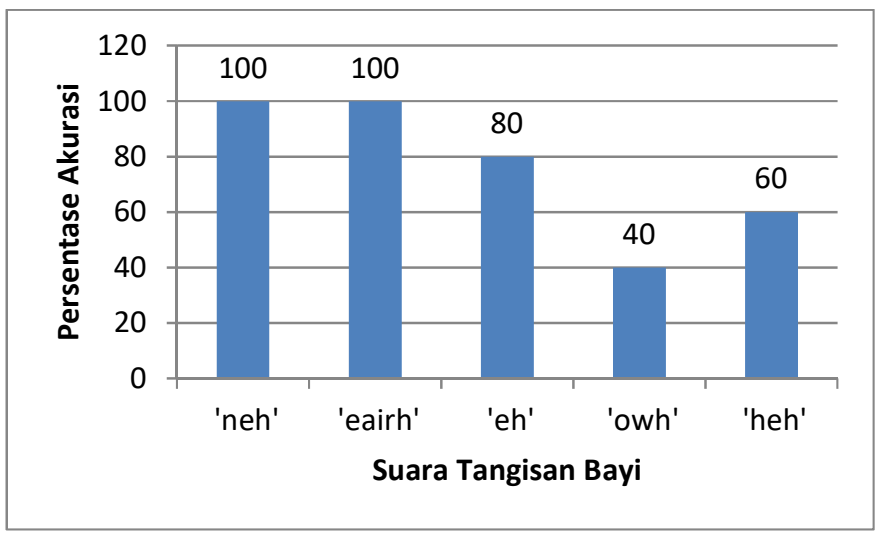

\section{Gambar 10. Persentase keberhasilan pendeteksian tangisan bayi}

Berdasarkan Gambar 10 persentase akurasi pendeteksian suara tangisan bayi terhadap 5 jenis suara yaitu 'neh' (lapar), 'eairh' (nyeri), 'eh' (ingin sendawa), 'owh' (lelah), 'heh' (tidak nyaman). Tingkat akurasi pendeteksian tertinggi suara tangisan bayi 'neh' (lapar) dan 'eairh' (nyeri) mencapai $100 \%$ sementara terendah adalah suara tangisan bayi 'owh' (lelah) mencapai $40 \%$. Hal tersebut dikarenakan nilai suara 'owh' mendekati nilai bobot pada jenis suara lain khususnya 'neh' dan 'eairh'. 
Dari data Gambar 10, diperoleh rata-rata persentase keberhasilan sistem mengidentifikasi suara tangisan bayi adalah:

$$
\text { Total Rata }=\frac{100 \%+100 \%+80 \%+40 \%+60 \%}{5}=76 \%
$$

Oleh karena itu, berdasarkan hasil pengujian dari penelitian identifikasi kebutuhan bayi usia 0-3 bulan melalui suara tangisan bayi menggunakan metode LPC mencapai keakurasian sebesar $76 \%$.

\section{KESIMPULAN}

Berdasarkan hasil penelitian yang diperoleh dari pengujian sistem yang menerapkan metode Linear Predictive Coding (LPC) dan algoritma Euclidean Distance, diperoleh kesimpulan sebagai berikut :

1. Aplikasi ini dapat mengidentifikasi suara tangisan bayi dengan Tingkat akurasi rata-rata mencapai $76 \%$.

2. Keberhasilan dalam proses identifikasi suara tangisan bayi paling besar mengidentifikasi suara uji "neh" (lapar) dan suara uji "eairh" (nyeri) dengan hasil persentase keberhasilan juga mencapai $100 \%$.

3. Pengidentifikasian suara tangisan 'owh' (lelah) dan 'heh' (tidak nyaman) memiliki bobot mendekati nilai ekstraksi ciri "eairh" (nyeri) pada data latih.

\section{DAFTAR RUJUKAN}

Ariyadi, R., Purnomo, M. H., Ramadijanti, N., \& Dewantara, B. S. (2016). Pengenalan rasa lapar Melalui Suara Tangisan bayi Umur 0-9 Bulan dengan Menggunakan Neural Network. Diambil kembali dari Researchgate.net: https://www.researchgate.net/publication/277150925_Pengenalan_Rasa_Lapar_Melalui _Suara_Tangis_Bayi_Umur_09_Bulan_Dengan_Menggunakan_Neural_Network_Sub_Judul_Penapisan_Dengan_Trans formasi_Wavelet_Kontinyu

Bhagatpatil, V., \& Sardar, V. (2014). An Automatic Infant's Cry Detection Using Linear. International Journal of Scientific \& Engineering Research, Volume 5, Issue 12, December2014, 1379-1383.

Brătilă, E., Comandasu, D., Diaconescu, Ş.-S., Rusu, M. S., \& Sardescu, G. (2015). Acquisition methodology of the newborn's crying. Diambil kembali dari Neonatologie: http://revistaginecologia.ro/system/revista/11/52-55.pdf

Deng, L., \& O'Shaughnessy, D. (2003). Speech Processing A Dynamic and OptimizationOriented Approach. New York: Marcel Dekker Inc.

Deza, Elena; Deza, Michele Marie. (2009). Encyclopedia of Distances. Berlin: Springer.

Dunstan, P. (2006). Open Up and Discover Your Baby's Language. Diambil kembali dari Babytaal.nl: http://www.babytaal.nl/media/PDF/ComprehensiveBooklet(2).pdf. 
Hariharan, M., Sindhu, R., \& Yaacob, S. (2012). Normal and Hypoacoustic Infant Cry Signal Classification Using Time -Frequency Analysis and General Regression Neural Network. Computer Methods and Programs in Biomedcine vol.108 No.2, 559-569.

Limantoro, W. S., Fatichah, C., \& Yuhana, U. L. (2016). Rancang Bangun Aplikasi Pendeteksian Suara Tangisan Bayi. Jurnal Teknik ITS vol 5 No.2.

Moeckel, E., \& Mitha, N. (2008). Textbook of Pediatric Osteopathy. Philadelphia: Elsevier Limited.

Permana, I., \& Negara, B. S. (2011). Identifikasi Pembicara dengan Menggunakan Mel Frequency Cepstral Coefficient (MFCC) dan Self Organizing Map (SOM). SNTIKI III, (hal. 209-216).

Poel, M., \& Ekkel, T. (2006). Analyzing Infant Cries Using a Committee of Neural Networks in order to Detect Hypoxia Related Disorder. International Journal on Artificial Intelligence Tools (IJAIT) Vol 15, No.3, 397-410.

Rabiner, Lawrence, \& Juang, B. H. (1993). Fundamentals of Speech Recognition. New Jersey: Prentice Hall.

Rachman, S. (2011). VISUALISASI PENGENALAN UCAPAN VOKAL BAHASA INDONESIA. Diambil kembali dari Diponegoro University Institutional Repository: http://eprints.undip.ac.id/25763/

Renanti, m. D., Buono, A., \& Kusuma, W. A. (2013). Identification by using Codebook as Feature Matching and MFCC as Feature Extraction. Journal of Theoretical and Applied Information Technology.

Smith, A. (2013). Decoding baby talk. Diambil kembali pada tanggal 20 Desember 2017 dari dunstanbaby: http://www.dunstanbaby.com/decoding-baby-talk/

Srijiranon, K., \& Eiamkanitchat, N. (2014). Application of Neuro-Fuzy Approaches to Recognition and Classification of Infant Cry. TENCON 2014-IEEE Region 10 Conference. Bangkok: TENCON.

Thiang, \& Saputra, H. (2005). Sistem Pengenalan Kata dengan Menggunakan Linear Predictive Coding. Jurusan Teknik Elektro, Universitas Kristen Petra, Vol 5, No.2, 19-24. 